\title{
Study Insight of Financial Sharing
}

\author{
Xuan Wang ${ }^{1, \text { a }}$ \\ ${ }^{1}$ Department of Accountancy, North China Electric Power University, Beijing, China 102200 \\ a979249051@qq.com
}

Keywords: Financial, ERP, Financial Sharing, Accounting Profession

Abstract. Financial shared service, which relies on information technology, is based on financial
process, and it aims at optimizing organization structure, standardizing process, improving process
efficiency, reducing operating cost and creating values. It is a distributed management mode that
provides professional production service to internal and external customers from market perspective.

\section{Introduction}

Financial Shared Connotation Mode, Software, Domestic and Foreign Research Status .

Financial shared service, which relies on information technology, is based on financial process, and it aims at optimizing organization structure, standardizing process, improving process efficiency, reducing operating cost and creating values. It is a distributed management mode that provides professional production service to internal and external customers from market perspective.[1]

The wide application of information technology has been the foundation of modern financial shared service. Most of the information technology application in financial shared service center is ERP financial mode, but it has the trend to transfer from ERP financial mode, ERP non-financial mode to ERP peripheral auxiliary system. At the same time, workflow, bill image, OCR recognition and other information technology tools are widely applied. The organization form of financial shared service center takes more consideration of process factor to strengthen professional labor division and improve production efficiency. No matter it is internal service or service management type, the financial shared service center should hold market perspective to pay critical attention to customers with satisfying service, so the operating motivation can be reflected in the service process. The financial sharing takes financial service to run the production and focuses on production efficiency and production quality to establish perfect on-site performance evaluation system and quality control system. In addition, the financial shared service center is regarded as server - side and the business unit is client-side to provide client/ service mode based distributed support. Financial shared service is a kind of management mode, including information technology, organization management, service management, quality management, performance management and other multiple management means.

The foreign research on financial sharing mainly focuses on the connotation of financial sharing, the difference between financial sharing and financial centralization \& outsourcing, characteristics, driving force, challenge, influence factor, optimized approach and other issues. There are many promising research fields in future financial sharing, such as customer perspective, shared organization form, information technology, shared visualization, control mechanism, outsourcing relationship and talent cultivation.

At present, softwares which can achieve financial sharing are as follows: Kingdee EAS \& yonyouNC, SAAS, CBS, SWIFT and Jiuhengxing.

\section{Case Analysis on Financial Sharing}

In order to have a better understanding of financial sharing, we study several cases by looking up information.

The first case is China Railway Construction, which is vertical, unitary and high-efficient. 
China Railway Construction Co., Ltd. was solely founded by China Railway Construction Corporation in Beijing on November 5h, 2007. It is a huge state-owned construction enterprise managed by State-owned Assets Supervision and Administration Commission. The organization hierarchy of China Railway Construction is complicated. It has one stock company finance, forty secondary groups, more than 700 third legal persons, more than 10000 fourth level engineering projects. The entire enterprise has multiple organization hierarchy and great amount of projects, and its accounting departments are located across the country and even all over the world. In addition, it has high project and personnel fluidity. The scale of entire enterprise is huge, and the financial management is much more difficult than other enterprises.

China Railway Construction started the feasibility study and construction on the financial shared center in June, 2012. An pilot project was started by the 2nd Engineering Co., Ltd of China Railway 17 Bureau Group Corporation in the end of 2012; To 2013, the pilot of 17 Bureau Group Corporation achieved successfully, and there were more than 680 online bill accounting departments in the whole group with 95.37\% online rate; four shared centers have been founded by August, 2014, including 15 Bureau Group Corporation, 17 Bureau Group Corporation, 18 Bureau Group Corporation and 20 Bureau Group Corporation; 11 corporation constructions have been founded by 2015. Above 5000 departments were calculated together and more than 6000 bank accounts were centralized managed. China Railway Construction successfully founded the first financial shared service center in domestic construction enterprise in 2014. Meanwhile, it was the first integrated imaging technique in domestic, applying China Telecom cloud service platform. The construction of this financial shared service center took the shortest time. Based on Telecom cloud platform and relying on the newest distributed technical framework, a great unification of the entire group system is achieved through the system centralized mode, which lays the largest FSSC scale supporting ability.

Internal accounting service agency, which is the organizational orientation of financial shared center, is office directly under the group. Its level is same with functional department, and the business is controlled by the financial department of group. Its main function is to help the financial department to formulate and carry out the accounting policy; it also does following work for internal member department, such as accounting calculation, fund settlement, report edit, asset value management, cost budget management, financial analysis and warning, accounting records management and so on. Authorized by the group, the financial shared center carries out parts of financial management and financial supervision.

To build up a vertical, unitary and high-efficient financial management system, the financial shared center of China Railway Construction carries out a scientific planning of process and position by formulating the process specification of different business activities. The financial shared center is divided into six departments and 16 positions. The accounting calculation is done from asset \& expense, income cost, general ledger statement, fund settlement, bill archive, operating management, which efficiently solves the large scale of production, multiple organization hierarchy, multiple enterprise sectors, wide construction area, low working efficiency, poor internal control and other issues. This financial shared center helps to control the risk, reduce the cost, enhance the efficiency and integrate the resources.

A significant effect is achieved after the construction of financial shared center, which enhances the management efficiency of the enterprise, improves the quality of accounting information and integrates the financial department' s work, including comprehensive budget, cost control, financial analysis, on-site management and auxiliary calculation. In addition, parts of calculation department achieve zero cash management. Excessive payment, pricing and distribution will be avoided in engineering projects. The financial department develops from the traditional accounting finance into an advanced business finance and strategic financial goals.

The second case is Huawei' s global shared center network which supports the global business development 
As a leading global information and communication technology solution provide whose products and solutions have been widely applied in more than 140 countries, Huawei' s financial organization focuses on how to better serve the enterprise to have a global business development.

Huawei has unified system specification and established financial shared centers in seven areas since 2006. The found of shared service center and improved network strengthen the head office' $s$ financial control of global business, which becomes the best guarantee to efficiently carry out the internal control of finance. At the same time, the constant promotion of process standardization and simplification greatly enhance the operating efficiency of the financial profess to make the financial function excellent and refined with leading management practice.

For Huawei, the build of global shared service network is a platform which processes global standardized financial accounting and manages the calculation. Huawei' s past 10 years' business development attributes to this platform which provides a good financial resource guarantee and risk control foundation for Huawei.

\section{The Influence and Enlightenment of Shared Finance on Accounting Profession}

The transformation from financial staff to financial accounting on one hand plays an advantage of traditional financial staff' $s$ accounting calculation to achieve financial centralized calculation and greatly enhance the financial efficiency; on the other hand, as financial talents cultivation base, the financial shared center provides talents for strategic finance and business finance.

The transformation from financial shared service center to shared financial staff can be divided into financial operator, key technician and operation administrator. They need to have necessary knowledge and skill. The financial operator is the direct producer in financial shared service center, similar to the workers in traditional factory. Financial operator does accounting calculation and fund settlement merely by the existing standard process. For the financial operators in the financial shared center, the demand on their professional skill and basic quality are not very high. What they need is certain of financial knowledge, English basis and computer operating skill. The transformation barriers can be eliminated through training.

Key technician is the core employee in the financial shared service center. Those technicians should be experts in financial informatization, standardization, optimized process, cost control, performance management, and internal risk control. The role they play is hard to be replaced in financial shared service center. It is difficult for the traditional financial staff to transform to key technician. So one can start from the financial operator to accumulate experiences and develop knowledge and skill to have a second transformation before being a technician in the financial shared center.

Operation administrator is mainly responsible for daily operation management of financial shared service center. They not only need to have financial accounting basis and deep understanding of business features, but also need to have integrated skills, such as team communication, coordination and organization. For the enterprises in early construction stage of financial shared service center, the talents in this position are scanty and often tend to have external recruitment. With the development and maturity of financial shared service center, the staffs, who gain the experience of financial shared internal operating management, will have more advantages in job selection. After GE, Oracle, ABB and other large-scale international groups establish the financial shared service center, the operation administrators become badly in need. The traditional financial staff will gradually accumulate experience to achieve transformation by learning new knowledge, participating training and furthering study.

The employees are divided into two levels by financial sharing. The intermediate level, which is subdivided, is replaced by information system. The first level is high-end financial policy maker, the second level is financial staff and business personnel in shared center. 
The found of financial shared center aims at processing the internal affairs of branch offices together to achieve scale effect to reduce operation cost. This aim decides the job nature is relatively simple, highly repetitive and alternative.

Obviously, the financial shared center solidifies the staff' $s$ thinking mode. Although it can give the answer to the procedure, hardly can it think why. This is an inevitable disadvantage caused by long0term repetitive work. As time passes, the financial staff will no longer focus on the financial accounting process and merely serve for the financial shared platform mechanically.

Everything has two sides. Different from the ordinary enterprise financial management mode, the advantages of financial shared service center are as follows: it reduces cost under scale effect, enhances financial management level and efficiency and meanwhile it benefits the core strategic development of enterprise. On the overall level, the financial sharing does make great contribution to the enterprise management.

\section{References}

[1] Malik M S, Kanwal L. Impact of Corporate Social Responsibility Disclosure on Financial Performance: Case Study of Listed Pharmaceutical Firms of Pakistan[J]. Journal of Business Ethics, 2016:1-10.

[2] Shahbaz M, Loganathan N, Tiwari A K, et al. Financial Development and Income Inequality: Is There Any Financial Kuznets Curve in Iran?[J]. Social Indicators Research, 2015, 41(2):1-26.

[3] Koch S, Inanc D. Mass customization for financial services: an empirical study of adoption and usage behavior[J]. Journal of Services Marketing, 2015, 29(3):235-243. 